\title{
LEADING LEARNING DESIGN: INVESTIGATING PROGRAM LEADERS' INITIAL CONCEPTIONS OF GRADUATE ATTRIBUTES
}

\author{
Kylie Readman \\ Office of Learning and Teaching \\ University of the Sunshine Coast, Australia \\ kreadman@usc.edu.au
}

\begin{abstract}
This paper reports on the perspectives of program leaders at a regional university, captured as they prepared to lead a program level curriculum renewal, driven by the introduction of a new set of graduate attributes. The aim of the research was to gain a deeper understanding of how program leaders anticipated leading changes to learning design by inviting them to reflect on the factors that impact on learning design in their program. The program leaders' perspectives were gathered via interview and sought to engage with program leaders' conceptualisation of their role as program leaders and their current understanding of graduate attributes in terms of perceived benefits and challenges. Barrie's (2003) framework for understanding what graduate attributes are and how they can be developed was used as a theoretical framework when analysing the data. The analysis also examined program leaders' views on what would constitute valid evidence of successful integration of graduate attributes into their programs.
\end{abstract}

Keywords

Program Leader, leadership, learning design, graduate attributes.

\section{Introduction}

This paper reports on the attitudes and beliefs of program leaders at a regional university, captured as they prepared to lead a curriculum renewal driven by the introduction of a new set of graduate attributes. In the organisational structure of the university, the program leader role is poorly defined, resulting in variable uptake of responsibilities for program learning design. Therefore the 'gatekeeper," "champion” or other role of the program leader in implementing graduate attributes was investigated as to the centrality of the role for the success of program redesign.

This pilot research was an important first step, as the National Graduate Attributes Project (GAP) identifies staff conceptions, the "different understandings people have about the very nature of graduate attributes” (Barrie, Hughes \& Smith, 2009, p. 3) as being influential in how academics approach learning design. Investigating the factors that impact on program leaders' approaches to leading learning (re)design to integrate graduate attributes was seen as significant in enhancing the probability of sustainable curricular change. The research draws on interviews with four program leaders that investigated their conceptions of how implementing graduate attributes would impact on the development of their program learning design.

\section{Graduate Attributes in Australian Higher Education}

The concept now known as graduate attributes, graduate capabilities or generic learning outcomes has the capacity to strengthen and transform graduates' domain content knowledge with qualities 
that are valued by universities, employers, disciplines, professional associations and by students themselves. The Higher Education Council Australia (1992) report Achieving Quality defined Graduate Attributes as "the skills, personal attributes and values which should be acquired by all graduates, regardless of their discipline or field of study” (p. 20). The report argued that, as universities were often judged on the quality of their graduates, each university must take responsibility for defining and developing such graduate skills within programs of study. The most recent review into higher education, the Bradley Review (2009) reiterated the needs employers expressed for "generic employability skills" such as communication and collaboration. The National GAP (Barrie, Hughes \& Smith, 2009) argued that graduate attributes of the kind described in most universities' profiles go beyond employability skills, preparing graduates to thrive in life not just in work.

Although there seems to be general agreement that development of graduate attributes is a valued outcome of a university education, Barrie (2004) argues that there is no empirical basis for such agreement. The lack of research may be the reason that implementation of graduate attributes based curriculum design and renewal has been inconsistent. Barrie’s (2003) research into how academic staff conceptualise graduate attributes and how students might develop them began the significant research into graduate attributes in Australia and this aspect of Barrie's original research is used as the theoretical basis for the pilot project reported in this paper.

Barrie (2003) reported that the academic staff he interviewed had variable understandings of what graduate attributes were. Barrie identified a hierarchy of four categories: precursor, complementary, translation and enabling. An academic who held precursor conceptions identified graduate attributes as basic skills that students should already possess on entering university. When complementary conceptions are present, graduate attributes are conceived of as general skills that round out or compliment a university education. Translation conceptions meant that academics saw graduate attributes as required for students to apply or make use of discipline knowledge. Finally, academics who expressed enabling conceptions saw graduate attributes as enabling learning and performance in the discipline; successful learning could not happen without the graduate attributes.

When it came to academics' understandings of how students acquire graduate attributes, Barrie (2003) presented six heirarchical conceptions. The first four, remedial, associated, teaching content and teaching process, all share a teacher focus whereas the final two, engagement and participatory, share a learner focus. An academic holding remedial conceptions does not see graduate attributes as part of the curriculum. Holding associated conceptions might mean that an academic sees graduate attributes taught as a specific subset of the curriculum. When teaching content conceptions are present, graduate attributes are taught explicitly but in the discipline context. For teaching process conceptions, graduate attributes are taught by choice of teaching activity. All of these focus on what the teacher is doing (or not doing) rather than on what the student is experiencing - they relate to inputs rather than outcomes. By contrast, an academic with engagement conceptions enables student engagement with graduate attributes through a course's learning design. Participatory conceptions extend this by including a student's engagement with the entire university experience as a series of opportunties for the student to acquire desired graduate attributes.

Organisational support for curriculum renewal of this kind is complex and often breaks down during implementation. The National GAP (Barrie, Hughes \& Smith, 2009, p. 41) identified a major challenge to curriculum renewal as being "the systemic and significant, cultural, attitudinal and practical shifts required in the approach taken by individual staff to designing curriculum and teaching”. Yet success also depends on structural opportunties such as funding, staffing and organisational preparedness for change. Green, Hammer and Star (2009) argue that in general the processes required to realise sustainable curricular changes via graduate attributes have been largely underestimated. When it comes to learning and teaching in higher education more broadly, Barnett and Coate (2005) believe that many initiatives have skirted around genuine engagement with the curriculum yet they argue that it is curriculum renewal that values high quality learning design that is most likely to deliver enhanced student learning outcomes. 


\section{Factors that impact on learning design}

Research undertaken by Scott, Coates and Anderson (2008) on academic leadership capabilities identifies program leaders (or Heads of Program) as the linchpin for making curriculum change happen. They characterise program leaders as "the final arbiter of whether a desired change is actually taken up and actioned locally...If these people do not engage then they will not focus and assist their staff to learn how to make the desired change work in practice.” (p. xvii). The Tertiary Education Quality and Standards Agency also acknowledges the centrality of program leaders in their teaching and learning standards discussion paper (2011) when considering how individual programs will evidence student learning against standards.

The introduction of a new set of graduate attributes requires a new learning design at the program level. Program leaders are responsible for the development of the program level learning design and thus can be considered to be learning designers. Koper and Tattersall (2005, p. 5) argue that effective learning design enables people to better learn and develop. Cameron (2009) is more attentive to the multiple meanings of the phrase "learning design," highlighting the various meanings attributed to it: an IMS-LD specification, a design process and a design product. Clarity around what is being produced and for what purpose is important if the process/product is to be meaningful for mainstream educators.

There are principles that enable the production of learning designs in a consistent and coherent manner, whatever the situation. These principles are likely to produce a better outcome than an adhoc approach. Oliver (2000) advocates for a constructivist approach to learning design, aligning the learning outcomes, teaching activities ans assessment to exploit the potential for learning most effectively. Beetham and Sharpe (2007) argue that learning design should be pedagogically intentional and that this intent can be brought to bear in design of resources, environments and learning activities, but also contingent in that pedagogical design responds to learners' needs as the learning and teaching takes place.

The final aspect that Beetham and Sharpe mention is the potential of learning designs to be shared across contexts which has been successful in institutional integration of graduate attributes.Biggs and Tang (2007) identify graduate attributes as generic learning outcomes for students at the university level which are realised in discipline specific program learning outcomes. Although the disciplinarity makes each program unique there is strong potential for intentional learning design to be shareable and transferable across contexts, giving rise to more sustainable approaches to curriculum change.

\section{Methodology}

The aim of this research was to understand the factors that influence or impact on program leaders' attitudes and beliefs in relation to graduate attributes and program leadership as this understanding may hold the key to enabling sustainable change. The research questions asked how program leaders view their role in designing learning, leading curriculum change and their attitudes and beliefs in relation to implementation of graduate attributes.

The research is based in the interpretivist-constructivist paradigm, which O’Donoghue (2007) says emphasises social interaction as the basis of knowledge. Howe (2001) argues that from an interpretive perspective, knowledge is "actively constructed, culturally and historically bound... and serving particular interests” (p. 202). Meanings are created via interactions between human beings in their everyday (in this case organisational) settings and the concern of the interpretivist is to understand how people define the events or reality that they experience (O’Donoghue, 2007).

Four program leaders from the discipline of Education were interviewed using a semi-structured interview format focusing on three key areas: their experience of leading learning in a higher education context, their conceptualisation of their role as program leaders and their current understanding of graduate attributes in terms of perceived benefits and challenges. The transcripts 
were then analysed using interpretational analysis to look for patterns within the data (Gall, Gall \& Borg, 2007)

The data generated were then analysed further comparing responses to Barrie’s (2003) conceptualisation of what graduate attributes are and how students might develop them. The categories generated by Barrie were utilised as a theoretical reference point to understand how the participants understood their role in leading learning design for graduate attribute implementation. The transcripts were also analysed to identify what program leaders thought would constitute valid evidence of integration of graduate attributes to a range of stakeholders.

\section{Findings and Discussion}

\section{Commonalities and differences in conceptualisation of the role of program leaders}

Curriculum leadership was identified by all program leaders as an important part of their role, even though all felt they were not able to commit as much time to it as was warranted. Probing during the interview revealed different conceptualisations of leadership from each program leader. The common elements that all program leaders spoke about in the domain of curriculum leadership were working from a research base and communicating with stakeholders, each to a greater or lesser extent. When considering research to inform learning design, program leader typically drew on research from their discipline (Education) particularly what was happening in schools and from the teacher education research, rather than research in higher education curriculum or learning design.

PL3: I looked at, when we were at the initial stages, at some of the work in Finland, but they've got a different society structure, so it's hard to implement something directly from there...you can still take some ideas out of that.

PL2: You have to do that research, the framework that supports your curriculum design and the rationale.

Communication was conceptualised as multi-modal. The most frequently mentioned participants in a communication exchange were the registration authority, university colleagues, employers and less frequently, students. The aim of communication was often to realise the aims of the program and achieve what one program leader called "philosophical alignment” between stakeholders. Two program leaders spoke about acting on feedback from students and two spoke about acting on feedback from the sector.

PL2: ...being able to speak to the program if there are committee meetings and reviewing, revising, as you receive feedback and information. I think part of it is then once it's rolled out you also have to induct other people that may be involved in the process of developing a program.'

PL2: 'students need to be inducted into why their program is designed in the way it is and what led us to that and what are the philosophical, well in my case it's about connecting philosophy, policy and practice.'

The differences in curriculum leadership centred around two main themes: how program leaders conceptualised their role and their own reported knowledge of learning design.

At the university, program leader is an ill-defined role and part of the purpose of this research was to enhance understanding of how program leaders understood their role in leading curriculum change. The program leaders presented a range of views. Even if compliance at the surface level was achieved uniformly, the degree to which a university curriculum initiative would be successful seemed to come down to the program leader's understanding of its value for their program. 
PL4: With the current structure we have... at the moment, more often than not it's me making overarching decisions about curriculum, about the direction that the programs are going to take and the way that curriculum's going to be delivered...It's not a democracy.

The complexity of leading other staff via influence rather than the positional power usually associated with a Head of School or Dean position also emerged from the interviews.

PL3: Dominant personalities can make a huge swing in a curriculum decision very easily. Someone takes over, things can move away from where you want them to be very quickly and asserting that change is something I need to practice.

The second area where program leaders differed was in their own knowledge of learning design and the extent to which they invested in the design aspects of program leadership. The age of the program and seemed to influence the amount of focus put on the learning design during the interviews, with leaders of the younger programs seeming to be more focused in that area. Some program leaders invested significant time in ensuring that students were receiving consistent messages.

PL1: I have had some shift with tutors by having those rich substantial conversations ourselves as educators prior to them commencing teaching in the course...We've actually given almost step by step in the tutorials about the sort of learning experiences we expect to ensure comparability because that's the other problem. When you have a lot of sessional staff, comparability between tutors is the bane of your existence.

Understandings about what program leadership is and the role of leading learning design within it have significant implications for the implementation of a new set of Graduate Attributes university-wide. This echoes Scott, Coates and Anderson's (2008) characterisation of the program leader as the linchpin for substantive curricular change. The commonalities program leaders identified could serve as a basis for moving forward together in the graduate attributes integration but interestingly, no program leader spoke about communicating or sharing ideas with other program leaders in the area of learning design.

\section{Alignment with Barrie's hierarchy}

Program Leaders tended to explain graduate attributes both in terms of their own work in leading learning design and in terms of students. Their explanations demonstrated some congruencies with Barrie's categorisation of academics' understandings of what graduate attributes are. It was interesting to note that the program leaders evidenced different levels of understanding through the interview, usually building on lower categories as they reflected more deeply.

No program leaders conceptualised graduate attributes as precursors to university entrance, but there was evidence of complementary conceptions of graduate attributes as a good positive skill set that put the finishing touches to a university education.

PL3: I think it's going to help in the development of our program having the graduate attributes. I just think somehow that we've got to become part of the bigger picture rather than something that no one places any real value on.

Translation conceptions were more common. Program leaders felt that using the graduate attributes in learning design would be legitimised because they are a university endorsed framework.

PL1: I think what graduate attributes allow me to do when I'm developing a course is align that course within the university vision for what a good graduate is.

Enabling conceptions were the most prevalent as program leaders saw student attainment of graduate attributes as important to successful employment. They also indicated that successful 
learning in the discipline of Education could not happen without acquisition of the graduate attributes.

PL2: Unless the students are reflecting on those or using that as part of their reference points for success or completion of a course, ultimately the program, then they are just empty statements. They have to be genuinely used, not just icons on a piece of paper.

PL4: It's pointless having a tertiary course that doesn’t contribute to any graduate attribute of the university.

All program leaders' perceptions about how students are likely to develop the graduate attributes were aligned to Barrie’s (2003) hierarchy. Program leaders focused on teaching the graduate attributes as content, using the graduate attributes as part of the teaching process and enabling students to engage with the graduate attributes.

\section{PL3: They need certain elements to be delivered to them.}

PL2: There's got to be a lot of modelling and demonstrating, how to be a good communicator, how to be collaborative, how to apply technology, how to be information literate.

PL4: The assessable items are the things that students do to demonstrate the outcomes for that course and therefore graduate attributes are part and parcel of that.

No program leaders spoke of students attaining graduate attributes through remediation or in distinct courses or modules (lower level of the hierarchy). Neither did program leaders speak of graduate attributes as something students could attain through participation in the whole university experience, the highest level that Barrie identified in his study.

\section{Challenges in learning design: mapping, integration and evidence of integration}

Mapping existing courses to the new graduate attributes was seen as a critical first step. All commented that academic staff need to genuinely engage with the graduate attributes for them to be more than a "tick and flick" exercise, a concern echoed in the literature (Barrie 2008; Oliver, Fern, Whelan \& Lilly, 2010) and some identified the possibility of mapping graduate attributes leading to a surface level engagement with the process.

PL4: The first thing we have to do is part of the course outline is to map the existing graduate attributes. To be honest that tends to be not high on the priority list, it's something that's considered but not considered deeply.

PL1: I think any auditing that we do, if we really do know that assessment is where students engage with university then we do need to look at our assessment tasks and the graduate attributes and I think that is a key auditing process that we need to go through.

PL4: So there's a mapping exercise that has to happen and I would say out of the six [graduate attributes] that are currently proposed I would be comfortable if they were only hitting three in each course, and I think that's more than appropriate, so that students, after they cover the entire program, will have multiply covered each attribute several times.

All program leaders spoke extensively about accreditation of their programs internally and by the external registration authority and the impact this had on learning design. For some it was a matter of compliance either internally or externally but for others an outcome of accrediting programs was to develop program cohesion, with a focus on graduate outcomes.

PL4: 'There's an external accreditation aspect and every time any curriculum is altered at a university level there's implications for that.' 
PL1: 'I feel like the alignment police person...I'm on constant surveillance looking at all of those spheres and how they're all connecting... It's because of program cohesion and in order for the graduates to have all the attributes, skills, content knowledge, pedagogical knowledge, all of those things that they need when they graduate to meet the standards.'

It is possible that the requirements of professional standards in externally accredited programs could have a deleterious effect on the impact of graduate attributes for students. These program leaders are all extremely conscious of professional accreditation and rated it as one of the most important aspects of their role. There was some reflection that the graduate attributes would have to take second place unless they fortuitously aligned with the professional standards.

PL3: I think they [students] are only going to do that if the graduate attributes actually mean something to them. You see, at the moment, registration requirements rule for them...I think the attributes have to be really valuable to the students and the only way to make them valuable is for the community to see them as valuable.

PL1: There's nothing like a tail to wag the dog.

Program leaders described many opportunities for gaining evidence of students' attainment of the graduate attributes. The approaches included mapping the graduate attributes, integration of graduate attributes through renewal of program and course outcomes, planning and teaching with the graduate attributes in mind and students' demonstration of graduate attributes, principally through assessment. Finally, program leaders felt that if the implementation of graduate attributes had been successful, students would be able to use the language of the graduate attributes in terms of their own learning, a benefit discussed in the following section.

A strong area of consensus was the role that assessment must play in students' ability to evidence the graduate attributes in the context of the discipline. This is well supported in the literature (Radloff, Scoulfis, Thomas \& David, 2008; de la Harpe, David, Dalton \& Thomas, 2009; Barrie, Hughes \& Smith, 2009) and examples of assessing graduate attributes as part of an integrated approach is well documented.

PL1: if we really do know that assessment is where students engage with university then we do need to look at our assessment tasks and the graduate attributes and I think that is a key auditing process that we need to go through.

PL4: I see a close alignment because in our course outlines the assessable items are the things that students do to demonstrate the outcomes for that course and therefore graduate attributes are part and parcel of that.

PL2: Ultimately we should be able to have some sort of assessable evidence, that yes, these graduate attributes are [assessed], the students do come out with the skills, generic skills and the attributes.

Interestingly, no mention was made of the quality assurance aspect of graduate attributes through the Australian Universities Quality Agency auditing. No program leaders referenced the impact of Tertiary Education Quality and Standards Agency or discipline standards on their program leadership. The only external accreditation body that rated significant mention was the professional accreditation body, whose endorsement of the program is required if graduates are to teach.

\section{Benefits of effective learning design: teaching enhancement, alignment and student engagement}

James, Lefoe and Hadi (2004) argue that the introduction of graduate attributes can open up a pedagogical space that requires a more holistic approach to teaching and learning. The program leaders agreed that the introduction of graduate attributes would have pedagogical implications for how course coordinators and tutors engage students in learning. One program leader suggested that 
academics (including herself) should self-audit against the graduate attributes prior to attempting to teach with or through them. The program leaders' responses below indicate that a commitment to fostering graduate attributes needs to be most effective when students and teachers attempt to realise a learning design.

PL2: They [graduate attributes] do need to be drivers of the delivery and what's being offered and the philosophical intent that people were putting behind the delivery...the learning and teaching activities, the assessment which you've come down to as well. Otherwise all those icons on the piece of paper don't mean anything.

PL1: The other thing I'm really interested in looking at at the moment is just whether or not our espoused philosophy in that what we say "walking the talk". We say that this is good pedagogy, we say that this is quality curriculum but are we doing it, are we modelling it?

One program leader argued that if the University was to set graduate attributes for students, these had to be modelled in university practices. In response to the question 'where should we be able to see the graduate attributes in practice?' the program leader responded, '....in our lectures, in our tutorials, in our committee meetings, even in the staff meetings. I think every place where people in the university are interacting, they should see those things. They should just be underlying elements...' A second program leader echoed these sentiments by saying graduate attributes have the potential of 'aligning what we do with the overall university, a common philosophy and teaching and learning philosophy driving what we're doing across the university.'

When asked how students might engage with graduate attributes, program leaders identified alignment of curriculum as an antecedent. Knight (2007) encourages program leaders to plan coherent curriculum aligned to graduate skills and favourable to overall learning goals rather than focusing at a course-by-course level. All program leaders also felt that the language of the graduate attributes had to be used in program outlines, course outlines, assessment descriptions and criteria for the alignment to be robust enough to both communicate effectively with students and withstand the influence of individual tutors or lecturers who may be resistant. The program leaders' understandings of alignment were consistent with Biggs and Tang's (2007) notion of constructive alignment;

PL1: So we should see alignment there between our [graduate] attributes, our learning outcomes, our assessment tasks.

PL2: I guess the challenge now is to keep on using the language of those graduate attributes and generic skills throughout the program, throughout the course development, throughout the assessment tasks.

Some program leaders felt that if integration of graduate attributes had been successful, students themselves would be able to use the language of the graduate attributes in terms of their own learning. Although a portfolio is a standard culminating task in the discipline, only one program leader mentioned a portfolio as a way for students to evidence their own attainment of the graduate attributes. By contrast, a second program leader did not prioritise this.

PL2: A portfolio about they're going across the program ongoing for four years, so as well as reflecting on those [the professional standards], they could...be reflecting on professional standards and the graduate attributes.

PL4: I probably don't think the university needs to formally evidence at the end...How's it going to be used unless you're a student who wanted to do that to demonstrate to a potential employer that these are the attributes that I have after studying at this university.

Considering Koper and Tattersall's (2005) view that effective learning design helps people to better learn and develop, the student's role is quite critical. Students can be (but were not in this research) positioned as learning designers as they should be active in shaping their graduate attributes, not "receive" them by virtue of graduation. Such a view behooves program leaders to 
design learning in such a way that there are opportunities for negotiation, independent learning and critical reflection with students to ensure that graduate attributes isn't another activity that happens to them rather than with them.

\section{Implications for further practice}

Working with program leaders to understand their existing conceptions of their role gives insight into (i) program leaders’ current approaches to learning design, (ii) program leaders’ current conception of graduate attributes, (iii) the challenges and benefits of renewing learning designs via graduate attributes integration and (iv) the strategies a university might develop to support learning design at the program level.

The pilot study showed that there was a strong base to begin from, particularly around key issues of learning design such as a constructivist approach, intentional and contingent design and curriculum alignment. Program Leaders responses also showed that they had clear conceptions of what graduate attributes were, how they can be developed and what would constitute valid evidence of student attainment. The program leaders interviewed were more likely to be "champions" of the learning design process rather than blocking it as they could see the potential of a curriculum renewal project to redesign their program. Therefore study gives a platform for program leaders to develop and extend their own understanding of learning design and enhance student engagement through graduate attributes, cognisant of the challenges and benefits they currently face.

Finally, the study makes known the central support services for learning and teaching (such as learning designers) to provide timely and specific resources and assistance to program leaders as they navigate the integration of graduate attributes into their programs, a learning design process in itself. The findings of this project contribute to a growing body of knowledge (see, for example, Barnett \& Coate, 2005; Barrie, Hughes \& Smith 2009; de la Harpe, David, Dalton \& Thomas, 2009; Healy, Bradford, Roberts \& Knight, 2010) about how universities can invest in policy development, planning and managing change that is sustainable over time and which results in enhanced learning outcomes for students. It provides a basis from which to develop evidence based implementation plans with consideration of those who have a significant stake in the learning design process.

\section{References}

Barnett, R., \& Coate, K. (2005). Engaging the curriculum in higher education. Berkshire. UK: Open University Press/ McGraw Hill.

Barrie, S. (2003). Conceptions of generic graduate attributes: A phenomenographic investigation of academics' understanding of generic graduate attributes in the context of contemporary university courses and teaching. Unpublished doctoral thesis. University of Technology, Sydney, Australia. Retrieved from Australasian Theses Database. (4006581)

Barrie, S. (2004). Academics' understandings of generic graduate attributes: A framework for assuring quality. Proceedings of the Australian Universities Quality Forum. Australian Universities Quality Assurance.

Barrie, S. (2008). Identity transitions: Developing graduate attributes. Keynote address at the Effective Learning and Teaching Conference, October 31 2008, QUT.

Barrie, S., Hughes, C. \& Smith, C. (2009) The national graduate attributes project: integration and assessment of graduate attributes in curriculum. Retrieved July 10, 2010, from http://www.itl.usyd.edu.au/projects/nationalgap/resources/GAPpdfs/National\%20Graduate\%20 Attributes\%20Project\%20Final\%20Report\%202009.pdf 
Beetham, H., \& Sharpe, R. (2007). An introduction to rethinking pedagogy for a digital age. In H. Beetham, \& R. Sharpe (Eds.), Rethinking Pedagogy for a Digital Age (pp. 1-10). Abingdon, UK: Routledge.

Biggs, J., \& Tang, C. (2007). Teaching for quality learning at university. ( $3^{\text {rd }}$ ed.). Berkshire, UK: Open University Press/ McGraw Hill.

Cameron, L. (2009). How learning design can illuminate teaching practice. The Future of Learning Design Conference. Paper 3. Retrieved $14^{\text {th }}$ September 2011 from http://ro.uow.edu.au/fld/09/Program/3

de la Harpe, B. David., C. Dalton, H., \& Thomas, H. (2009). Are confidence and willingness the keys to the assessment of graduate attributes? Proceedings of the ATN Assessment Conference, RMIT, Melbourne.

Department of Education, Employment and Workplace Relations (2008) Review of Australian Higher Education. Retrieved 16 August, 2010 from http://www.deewr.gov.au/highereducation/ review/pages/reviewofaustralianhighereducationreport.aspx

Department of Education, Employment and Workplace Relations (2011) Developing a framework for teaching and learning standards in Australian higher education and the role of TEQSA. Retrieved $10^{\text {th }}$ August 2011 from http://www.deewr.gov.au/HigherEducation/Policy/teqsa/ Pages/TeachingandLearningStandardsDiscussion.aspx

Gall, M., Gall, J. \& Borg, W. (2007). (8th ed). Educational research: an introduction. Boston, Pearson.

Green, W., Hammer, S., \& Star, C. (2009). Facing up to the challenge: Why is it so hard to develop graduate attributes. Higher Education Research and Development, 28 (1), pp. 17-29.

Healy, M., Bradford, M., Roberts, C. \& Knight, Y. (2010). GEES Subject Centre Departmental Change Initiative: Bringing about change in learning and teaching at the departmental level. Retrieved 15 July, 2010 from http://www.gees.ac.uk/events/2009/deptcccchg09/deptchg09.htm

Higher Education Council Australia (1992). Achieving quality. Higher Education Council, National Board of Employment, Education and Training. Canberra: Australian Government Publishing Service.

Howe, K. (2001). Qualitative educational research: The philosophical issues. In V. Richardson (Ed.), Handbook of research on teaching (pp. 201-208). Washington, DC: American Educational Research Association.

James, B., Lefoe, G., \& Hadi, M. (2004). Working “through" graduate attributes: A bottom up approach. In F. Sheehy \& B. Stauble (Eds.), Transforming Knowledge into Wisdom: Holistic Approaches to Teaching and Learning. Proceedings of Higher Education Research and Development Society. 27, (pp. 174-184). Sarawak: HERDSA. Available at http://www.herdsa.org.au/conference2004/Contributions/RefereedPapers.htm

Knight, P. (2007). Fostering and assessing "wicked" competences. Retrieved September 15, 2010 from http://www.open.ac.uk/pbpl/resources/details/detail.php?itemId=460d2370a2b6b

Koper, R., \& Tattersall, C. (2005). Learning design: A handbook on modelling and delivering networked education and training. Berlin: Springer.

O'Donoghue, T. (2007). Planning your qualitative research project. London: Routledge.

Oliver, B., Ferns, S., Whelan, B., \& Lilly, L. (2010). Mapping the Curriculum for Quality Enhancement: Refining a Tool and Processes for the Purpose of Curriculum Renewal. Paper presented at the Australian Universities Quality Forum 2-3 July 2010, Gold Coast, Queensland.

Oliver, R. (2000). When teaching meets learning: Design principles and strategies for web-based learning environments that support knowledge construction. In Proceedings of ASCILITE 2000 conference, Coffs Harbour, Australia, 17-28.

Radloff, A. H., B. Scoulfis, M. Thomas, A., \& David, C. (2008). The BFactor project: Understanding academic staff beliefs about graduate attributes; Academic Teaching Staff Survey. Australian Teaching and Learning Council. 
Scott, G., Coates, H., \& Anderson, M., (2008). Learning leadership in times of change: Academic Leadership Capabilities for Australian Higher Education. Higher Education Research.

Retrieved $20^{\text {th }}$ July 2011 from http://research.acer.edu.au/higher_education/3

\section{Acknowledgments}

I would like to acknowledge the program leaders who contributed to this study for their time and insight. Further, I would like to thank my writers' group who gave feedback on an initial draft of this paper and the reviewers whose helpful comments certainly improved the quality of the final product.

Copyright $\odot 2011$ Kylie Readman 